\title{
Pemberdayaan Desa Wisata Samiran Boyolali (Dewi Sambi) berdasarkan Teori Analisis TALC (Tourism Area Life Cycle) \\ Empowerment of Samiran Boyolali Tourism Village (Dewi Sambi) based on TALC (Tourism Area Life Cycle) Analysis Theory
}

\author{
Risky Ayu Andriani*, Agung Wibowo, Joko Winarno \\ Program Studi Penyuluhan dan Komunikasi Pertanian, Fakultas Pertanian, \\ Universitas Sebelas Maret, Surakarta, Indonesia \\ Email : riskyayuandriani123@gmail.com
}

\begin{abstract}
Research on the development conditions of the Samiran Boyolali (Dewi Sambi) tourism village based on the TALC (Tourism Area Life Cycle) analysis theory is a descriptive qualitative study. The research location was determined purposively in Samiran Village, with the consideration that the Samiran tourism village was the first tourism village formed in Selo District together with the Lencoh tourism village in 2002. The purpose of this study was to investigate the process of empowering Dewi Sambi and identify the development of Dewi Sambi based on theory TALC. The determination of the informants was carried out by purposive sampling for key informants, while the advanced informants used snowball techniques based on recommendations from key informants. The number of informants in this study were 7 people including community leaders, village heads, managers, and members of Dewi Sambi. The data analysis technique of this research used the interactive inductive analysis method. Meanwhile, the validity of research data uses triangulation of sources and informant reviews. The results showed that the process of empowering Dewi Sambi went through 3 stages, namely the stage of awareness, breathing and power. These three stages were passed with the result that most of the people of Samiran Village joined Dewi Sambi and negative behavior began to wear off. The results of research on the development conditions of Dewi Sambi based on TALC, show that this tourism village is in a consolidation phase. The main characteristics that appear are the implementation according to regulations, the number of tourists fluctuating but tends to increase according to tourist visit chart, and the role of the ministry or government to improve services to tourist guests
\end{abstract}

Keywords: Community Empowerment, TALC, Tourism Village

\begin{abstract}
Abstrak
Penelitian mengenai kondisi pengembangan desa wisata Samiran Boyolali (Dewi Sambi) berdasarkan teori analisis TALC (Tourism Area Life Cycle) ini merupakan penelitian kualitatif deskriptif. Lokasi penelitian ditentukan secara purposive area di Desa Samiran, dengan pertimbangan desa wisata Samiran merupakan desa wisata yang pertama kali dibentuk di Kecamatan Selo bersama dengan desa wisata Lencoh pada tahun 2002. Tujuan penelitian ini untuk mengetahui proses pemberdayaan Dewi Sambi dan mengidentifikasi perkembangan Dewi Sambi berdasarkan teori TALC. Penentuan informan dilakukan secara purposive sampling untuk key informan, sedangkan informan lanjutan menggunakan teknik snowball atas rekomendasi dari key informan. Jumlah informan dalam penelitian ini yaitu 7 orang yang meliputi tokoh masyarakat, kepala desa, pengelola, dan anggota Dewi Sambi. Teknik analisis data penelitian ini menggunakan metode analisis induktif interaktif. Sedangkan, validitas data penelitian menggunakan triangulasi sumber dan review informan. Hasil penelitian menunjukkan bahwa proses pemberdayaan Dewi Sambi melewati 3 tahapan yaitu tahap penyadaran, pengapasitasan, dan pemberian daya. Ketiga tahapan tersebut dilewati dengan hasil sebagian besar masyarakat Desa Samiran bergabung ke Dewi Sambi dan perilaku negatif mulai luntur. Hasil penelitian dari kondisi perkembangan Dewi Sambi berdasarkan TALC, menunjukkan bahwa desa wisata ini berada pada fase consolidation atau penggabungan. Ciri utama yang tampak adalah penyelenggaraan sesuai peraturan, jumlah wisatawan fluktuatif namun cenderung meningkat sesuai pada grafik kunjungan wisatawan, dan adanya peran kementrian atau pemerintah untuk memperbaiki pelayanan kepada tamu wisata.
\end{abstract}

Kata kunci: Desa Wisata, Pemberdayaan Masyarakat, TALC

Cite this as: Andriani, R., Winarno, J., \& Wibowo, A. (2021). Pemberdayaan Desa Wisata Samiran Boyolali (Dewi Sambi) berdasarkan Teori Analisis Talc (Tourism Area Life Cycle). AGRITEXTS: Journal of Agricultural Extension, 45(1), 59-67. doi:http://dx.doi.org/10.20961/agritexts.v45i1.51540 


\section{PENDAHULUAN}

Indonesia merupakan negara yang memiliki kekayaan alam melimpah. Hampir di daerah memiliki tempat wisata. Hal ini sejalan dengan pendapat Rani (2014) menyatakan bahwa pariwisata menjadi salah satu primadona bagi negara-negara dalam meningkatkan sumber pendapatannya diluar migas dan pajak. Saat ini Indonesia sebagai salah satu negara berkembang mulai mempromosikan negaranya untuk menarik pandangan mata dunia. Hal ini dimaksudkan agar Indonesia semakin terkenal bagi warga atau penduduk negara lain untuk berkunjung ke Indonesia. Indonesia memiliki keragaman budaya dan wisata melimpah, hal tersebut untuk penguatan ekonomi dari penerimaan devisa atau pendapatan daerahnya.

Salah satu keragaman budaya dan wisata yang melimpah dapat ditelisik melalui desa wisata. Desa wisata menyuguhkan suasana pedesaan yang masih asri, aktivitas sehari-hari masyarakat pedesaan, beserta budaya lokalnya. Hal ini sejalan dengan pendapat Zakaria et al. (2014), bahwa desa wisata adalah suatu wilayah pedesaan yang menawarkan keaslian baik dari segi sosial budaya, adat-istiadat, keseharian, arsitektur tradisional, struktur tata ruang desa yang disajikan dalam suatu suatu bentuk integrasi komponen pariwisata antara lain seperti atraksi, akomodasi dan fasilitas pendukung. Di kawasan ini, penduduknya masih memiliki tradisi dan budaya yang relatif masih asli. Selain itu, faktor pendukung seperti makanan khas, sistem pertanian dan sistem sosial turut mewarnai sebuah kawasan desa wisata. Di luar faktor-faktor tersebut, alam dan lingkungan yang masih asli dan terjaga merupakan salah satu faktor terpenting dari sebuah kawasan tujuan wisata.

Desa wisata adalah desa yang memiliki potensi keunikan dan daya tarik wisata yang khas, baik berupa karakter fisik lingkungan alam pedesaan maupun kehidupan sosial budaya kemasyarakatan. Potensi ini dikelola dan dikemas secara menarik dan alami dengan pengembangan fasilitas pendukung wisatanya. Suatu tata lingkungan yang harmonis dan pengelolaan yang baik dan terencana mampu menggerakan aktivitas ekonomi pariwisata yang dapat meningkatkan kesejahteraan dan pemberdayaan masyarakat setempat (Atmoko, 2014). Indikator sosial ekonomi pengembangan wisata berbasis masyarakat menurut Jamalina dan Dyah (2017) meliputi dana, pendapatan masyarakat, lapangan kerja, kualitas hidup meningkat, rasa bangga terhadap desanya, organisasi komunitas seperti karang taruna menguat, masyarakat lebih sadar terhadap lingkungan, dan ada kerjasama antara generasi muda dan tua untuk mengembangkan pariwisata.

Kawasan tujuan wisata yang menarik untuk dikunjungi salah satunya adalah desa wisata Samiran Boyolali atau merupakan kependekan dari Dewi Sambi. Desa wisata tersebut menampilkan aktivitas keseharian penduduk lokal yang kental dengan budaya setempat. Dewi Sambi merupakan desa wisata yang dibangun karena adanya potensi alam pegunungan dan dampak positif dibukanya jalur SSB (Solo-Selo-Borobudur) pada tahun 2002. Berdasarkan potensi tersebut, Dewi Sambi ditetapkan oleh pemerintah Kabupaten Boyolali pada tahun 2009. Keberlanjutan desa wisata tersebut hingga sekarang menjadikan Dewi Sambi sebagai desa wisata pioner di Kabupaten Boyolali.

Aspek pemberdayaan merupakan kunci dari keberlanjutan desa wisata unggulan. Sama halnya dengan Dewi Sambi yang mengusung konsep pemberdayaan masyarakat. Menurut Arifudin et al. (2013), dalam hal pengetahuan adat, pemberdayaan masyarakat adalah proses yang mengembangkan dan memperkuat kemampuan masyarakat pedesaan untuk terlibat dalam pembangunan pedesaan yang berkelanjutan. Indikatornya adalah pertumbuhan kapasitas dan motivasi orang untuk dapat menyelesaikan masalah dan dapat membuat keputusan bebas sesuai pilihannya. Pemberdayaan menurut Darwis (2012), adalah proses dimana individu, organisasi, atau kelompok yang dalam kondisi tidak berdaya (powerless) menjadi sadar dan tahu (having knowledge) akan dinamika kekuasaan yang bekerja dalam konteks kehidupan mereka, menjalankan (exercise) kontrol tanpa mengganggu hak-hak orang lain dan mendukung upaya pemberdayaan (individu atau kelompok) lain dalam masyarakat. Steiner dan Farmer (2017) menyatakan bahwa keberhasilan implementasi kebijakan pemberdayaan masyarakat membutuhkan struktur dan dukungan yang tepat.

Sejak awal Dewi Sambi ditetapkan sebagai desa wisata, telah terbentuk suatu kelompok dari masyarakat yang dinamakan kelompok sadar wisata (Pokdarwis). Kelompok ini dibentuk bertujuan untuk mengorganisir dan sebagai pengelola utama desa wisata. Pokdarwis yang 
ada di Desa Samiran bernama Pokdarwis Guyub Rukun. Sebelumnya Pokdarwis Guyub Rukun hanya mengakomodasi homestay Desa Samiran, namun karena dilihat adanya potensi wisatawan maka pokdarwis membentuk desa wisata Samiran Boyolali.

Dewi Sambi terletak dalam jalur SSB yang sebagai jalur alternatif yang menghubungkan Solo, melewati Boyolali, menuju ke Magelang. Sejak dibukanya jalur tersebut muncul potensi kunjungan wisatawan untuk mendaki Gunung Merapi atau Merbabu. Oleh karena itu, peneliti tertarik untuk meneliti proses pemberdayaan lebih lanjut. Tujuan dari penelitian ini untuk mengetahui proses pemberdayaan Dewi Sambi dan mengidentifikasi sampai tahap mana kondisi perkembangan pemberdayaan Dewi Sambi.

\section{METODE PENELITIAN}

Penentuan lokasi penelitian dilakukan secara purposive area, dengan pertimbangan Desa Samiran merupakan desa wisata yang pertama kali dibentuk di Kecamatan Selo bersama dengan desa wisata Lencoh pada tahun 2002. Desa Samiran merupakan desa wisata pioner di Kabupaten Boyolali.. Lokasi penelitian ini di desa wisata Samiran Boyolali (Dewi Sambi) terletak di Desa Samiran Kecamatan Selo. Lokasi penelitian berada $21 \mathrm{~km}$ dari kota Boyolali.

Jenis data yang digunakan adalah kualitatif, yaitu berupa uraian data informasi yang dijabarkan secara rinci dan jelas untuk menarik suatu simpulan. Data tersebut berupa hasil wawancara, pengamatan lapangan, dan dokumentasi. Penelitian ini menggunakan pendekatan kualitatif yaitu pendekatan untuk memahami fenomena pemberdayaan di desa wisata Samiran Boyolali.

Sumber data yang digunakan adalah data primer merupakan data dari sumber informan berupa hasil wawancara yang dilakukan oleh peneliti secara langsung pada lokasi penelitian melalui prosedur dan teknik pengumpulan data. Data primer ini berupa catatan hasil wawancara, hasil observasi ke lapangan secara langsung dalam bentuk catatan tentang situasi dan kejadian. Data tersebut adalah data yang berupa kata, kalimat, skema, dan gambar yang merupakan kata kunci dalam penelitian yang berkaitan dengan Dewi Sambi. Data sekunder adalah data yang didapat secara tidak langsung dari hasil penelitian-penelitian mengenai Dewi Sambi yang dilakukan oleh orang lain atau instansi yang telah dipublikasikan dalam bentuk buku, artikel ilmiah, dan laporan penelitian.

Instrumen penelitian adalah alat bantu yang digunakan untuk mendukung proses pengambilan data penelitian. Adapun alat yang digunakan dalam mengumpulkan data antara lain : tape recorder, catatan kecil, serta alat tulis untuk mencatat hasil observasi saat melaksanakan wawancara. Dimana peneliti tetap berfungsi menetapkan fokus penelitian, memilih informan, mengumpulkan data, menganalisis data, dan menyajikan data, serta membuat simpulan atas penelitiannya.

Teknik pengumpulan data dalam penelitian ini melalui observasi, wawancara mendalam, dan metode dokumentasi. Dimana peneliti dapat menentukan dan memilih informan penelitian tersebut sebagai key informan. Key informan dalam penelitian ini yaitu tokoh masyarakat setempat yang mengetahui mengenai wisata di Boyolali. Informan lanjutan ditentukan dengan teknik snowball. Adapun informan lanjutannya adalah kepala desa, pengelola, dan anggota Dewi Sambi. Jumlah informan penelitian berjumlah 7 orang.

Teknik analisis data menggunakan analisis induktif interaktif, melalui beberapa tahapan yaitu: a. Pengumpulan data, data hasil wawancara yang telah didapat itu kemudian dipahami makna apa yang dimaksud dalam wawancara tersebut. Makna yang mendalam akan di dapat melalui wawancara yang mendalam. b. Reduksi data, data yang didapat tersebut kemudian dipilah-pilah, jika sesuai dengan apa yang diinginkan peneliti. c. Penyajian data, menyajikan data yang telah diklasifikasikan melalui metode deskriptif atau penggambaran data secara narasi agar mudah dipahami dan didukung dengan bagan maupun grafik yang mewakili hasil penelitian serta hasil wawancara mendalam, sehingga menjawab tujuan penelitian untuk menganalisis proses pemberdayaan dan kondisi perkembangan Dewi Sambi. Dimana sebelumnya data tersebut diolah, ditafsirkan, dan dimaknai. d. Penarikan kesimpulan, menarik suatu kesimpulan berdasarkan analisis secara cermat dan mendalam terhadap data-data yang diperoleh, sehingga terjawablah permasalahan yang dihadapi peneliti.

Validitas data menggunakan triangulasi sumber dan review informan. Review informan yang dilakukan peneliti dalam penelitian ini, peneliti mewawancarai secara mendalam kepada sejumlah informan kemudian hasil wawancara tersebut di 
cek kebenarannya pada key informan. Triangulasi sumber menurut Sugiyono (2010), merupakan pengecekan data yang diperoleh kepada sumber / informan yang berbeda-beda dengan tujuan memperoleh pandangan berbeda dari tokoh masyarakat, kepala desa, pengelola dan anggota Dewi Sambi dengan menggunakan satu metode yang sama untuk mengurangi bias atau kesalahan pada waktu pengumpulan dan analisis data. Penggunaan triangulasi sumber dengan review informan dalam penelitian ini saling melengkapi. Triangulasi sumber lebih membandingkan data hasil pengamatan dengan data hasil wawancara, membandingkan dengan apa yang dikatakan di depan umum dengan apa yang dikatakan secara pribadi, dan membandingkan wawancara dengan dokumen yang berkaitan. Sedangkan review informan lebih ke mengkomunikasikan hasil analisis yang telah dilakukan dengan key informan.

\section{HASIL DAN PEMBAHASAN}

\section{Proses Pemberdayaan Dewi Sambi}

Dewi Sambi merupakan desa wisata yang dibentuk atas prakarsa masyarakat lokal dengan tujuan pemerataan pemberdayaan. Pencapaian tersebut tidak lepas dengan adanya proses pemberdayaan yang dilakukan, baik oleh pengelola maupun pemerintah Boyolali. Menurut Sutawa (2012), pemberdayaan masyarakat adalah kunci utama untuk mengembangkan kesejahteraan masyarakat melalui pariwisata. Proses pemberdayaan yang dilakukan diharapkan membentuk menjadi orang-orang yang memiliki ketergantungan kemampuan untuk mengambil keputusan dan mengimplementasikan keputusan untuk meningkatkan kesejahteraan mereka. Andriyani et al. (2017) menyatakan proses pemberdayaan masyarakat melalui pengembangan desa wisata meliputi tiga tahapan, yaitu tahap penyadaran, tahap pengapasitasan, dan tahap pemberian daya.

\section{Tahap Penyadaran}

Tahap penyadaran merupakan tahap sebelum adanya pembentukan desa wisata. Pada tahapan ini masyarakat Desa Samiran diberikan sosialisasi dan pemahaman mengenai desa wisata oleh Pokdarwis Guyub Rukun. Menurut Sururi (2013), kendala pemberdayaan salah satunya disebabkan karena kurangnya pemahaman masyarakat mengenai makna pemberdayaan dan sosialisasi yang diberikan fasilitator dan perangkat kelembagaan desa. Sebagian masyarakat di Desa Samiran sudah menyadari adanya potensi alam berupa Gunung Merapi dan Merbabu. Sebelum ditetapkan sebagai desa wisata, Desa Samiran merupakan desa yang ditunjuk untuk mendirikan 100 homestay bersama dengan Desa Lencoh pada pembukaan jalur SSB (Solo-Selo-Borobudur). Berbekal homestay dan potensi pegunungan yang dimiliki, Pokdarwis Guyub Rukun menyosialisasikan mengenai pembentukan desa wisata. Pada awal tahap ini, banyak masyarakat Desa Samiran menolak dan meremehkan desa wisata. Banyak tantangan yang dilalui oleh pengelola Dewi Sambi untuk menyadarkan masyarakat, salah satunya adalah sulitnya mengubah perilaku masyarakat untuk tidak membuang kotoran ternak di selokan depan rumah dan menjemur pakaian di jalan.

Desa Samiran merupakan desa yang memiliki budaya yang masih kental hingga saat ini masih dilestarikan. Kesenian jalan berupa tarian tradisional dimiliki hampir seluruh desa di Kecamatan Selo, termasuk Desa Samiran. Adanya ragam tarian tersebut juga dijadikan potensi budaya dalam pembentukan desa wisata. Tarian yang berkembang di Desa Samiran adalah tari soreng dan bujang ganong. Umumnya tarian-tarian tersebut muncul karena keseharian masyarakat lokal. Selain budaya kesenian jalan, juga terdapat situs peninggalan keraton Solo dan budaya sedekah gunung. Masyarakat Desa Samiran mengetahui dengan pasti, bahwa ada beberapa tempat wisata di Desa Samiran yang dilindungi pemerintah dan dijadikan destinasi wisata.

Pokdarwis Guyub Rukun menyadari bahwa di Desa Samiran merupakan desa yang memiliki nilai sejarah dan potensi tinggi untuk dikunjungi wisatawan. Pengelola mengemas potensi-potensi tersebut dan dipaparkan kepada masyarakat Desa Samiran yang disisipkan dalam sosialisasi umum yang diselenggarakan pemerintah desa. Beberapa masyarakat pemilik homestay yang bergabung dalam Dewi Sambi, merasakan adanya manfaat ekonomi. Hal ini sejalan dengan pendapat Hermawan (2016), bahwa dampak pariwisata terhadap kondisi ekonomi salah satunya adalah dampak penerimaan pendapatan masyarakat, kesempatan kerja, dan distribusi manfaat atau keuntungan. Pendapat tersebut diperkuat Wibowo (2017), pendapatan dari desa wisata akan 
membantu masyarakat memenuhi kebutuhan sehari-hari, meskipun bukan pendapatan utama. Secara tidak langsung akan menimbulkan rasa memiliki dan rasa tanggung jawab masyarakat terhadap desa wisata. Sebagian masyarakat Desa Samiran bermata pencaharian sebagai petani sayur harus menunggu 3 bulan, namun ketika bergabung di desa wisata ada tambahan penghasilan yang cukup. Berdasarkan manfaat tersebut, secara tidak sengaja beberapa masyarakat Desa Samiran menyampaikan kepada masyarakat lainnya (mouth to mouth).

\section{Tahap Pengapasitasan}

Tahap pengapasitasan merupakan tahap pemberian kapasitas kepada masyarakat untuk mengelola desa wisata. Tahap pengapasitasan menurut Wrihatnolo dan Dwidjowijoto (2007) terdiri dari 3 yaitu pengapasitasan manusia, pengapasitasan kelompok, dan pengapasitasan sistem nilai. Pengapasitasan manusia di Dewi Sambi diterapkan dalam bentuk pelatihanpelatihan untuk meningkatkan kapasitas SDM (Sumber Daya Manusia) khususnya anggota Dewi Sambi. Pelatihan tersebut merupakan salah satu perwujudan pemerintah untuk mendukung keberlanjutan desa wisata. Pemerintah Kabupaten Boyolali maupun Provinsi Jawa Tengah memberikan pelatihan bagi pengelola homestay dan guide pada setiap perwakilan desa wisata yang ditunjuk. Pelatihan-pelatihan tersebut menjadi bekal pemilik-pemilik homestay Dewi Sambi mengenai bagaimana cara menerima dan melayani tamu homestay, indikator kebersihan homestay, dan sebagainya. Pelatihan guide memberikan kapasitas bagaimana cara menyampaikan informasi kepada wisatawan, cara berpenampilan, komunikasi, dan memfasilitasi wisatawan untuk memandu kegiatan di desa wisata. Terbatasnya kuota pelatihan yang diberikan oleh pemerintah, menjadikan pengelola Dewi Sambi menggilir kepada setiap pemilik homestay maupun guide untuk mengikuti pelatihan. Selain pelatihan, pemerintah juga memberikan kesempatan untuk desa-desa wisata yang ditunjuk untuk mengikuti studi banding ke desa wisata yang sudah maju.

Dukungan Pemerintah Kabupaten Boyolali dalam pengapasitasan kelompok diterapkan melalui pemberian kesempatan kepada desadesa wisata di Boyolali untuk mewakili lomba desa wisata. Anggota dan pengurus Dewi Sambi dibagi menjadi beberapa kelompok kontingen untuk diikutkan lomba. Setiap kelompok mewakili cabang lomba. Pengapasitasan kelompok Dewi Sambi tampak pada latihan maupun persiapan sebelum maju lomba. Adanya pengetahuan dan keterampilan baru mengenai pariwisata menjadi poin utama yang didapatkan ketika mengikuti lomba. Antusiasme masyarakat Desa Samiran dalam mengikuti perlombaan manjadi sisi positif dari pengembangan desa wisata. Dewi Sambi meraih beragam juara baik dari segi pemberdayaan masyarakat, desa wisata, maupun pokdarwis. Namun, dana yang diberikan pemerintah Boyolali tidak mampu menutup semua biaya lomba, termasuk menyiapkan pernak-pernik hasil bumi yang dibawa untuk pameran desa wisata. Oleh karena itu, Dewi Sambi menggunakan uang kas untuk menutup kekurangan biaya lomba.

Pengapasitasan sistem nilai merupakan pengapasitasan yang dilakukan setelah manusia dan kelompok sudah dikapasitaskan. Pengapasitasan sistem nilai di Dewi Sambi berjalan dengan bertahap. Pembuatan dan persetujuan aturan baru dilakukan bersama melalui musyawarah setiap berkumpul. Pengurus dan anggota Dewi Sambi dalam struktur organisasi berjalan sesuai dengan tugas pokok dan fungsinya. Pemilihan regenerasi Dewi Sambi dilakukan secara kebersamaan. Dewi Sambi juga sudah memiliki AD/ART sebagai dasar pengelolaan.

\section{Tahap Pemberian Daya}

Tahap pemberian daya merupakan tahapan yang diberikan oleh stakeholder untuk menunjang keberlanjutan desa wisata. Hal ini selaras dengan pendapat Febriani et al. (2014), parameter objek wisata dipengaruhi aspek indikator aksesibilitas, akomodasi, informasi pariwisata, infrastruktur dan suprastruktur seiring bertambahnya jumlah wisatawan. Pada tahapan ini, dari aspek akomodasi pemerintah Kabupaten Boyolali memberikan bantuan renovasi homestay dan toilet yang dilaksanakan dalam 2 tahap ketika awal pencanangan 100 homestay. Aspek aksesibilitas jalan menuju desa wisata diperbaiki hingga sampai depan homestay menggunakan paving. Aspek infrastruktur dan suprastruktur, Dewi Sambi dan desa wisata Nglanggeran merupakan dua desa wisata yang dipercaya oleh Kementrian Keuangan untuk pemberian pinjaman dana sebanyak Rp830.000.000 (delapan ratus tiga 
puluh juta rupiah) digunakan untuk renovasi homestay tanpa agungan dan tanpa bunga. Bantuan tersebut diberikan pada awal tahun 2019 hingga lima tahun kedepan. Informasi pariwisata didukung oleh pemerintah Kabupaten Boyolali yang dipromosikan melalui web resmi Disporapar (Dinas Pemuda, Olahraga, dan Pariwisata) Boyolali, baliho event pariwisata Boyolali, dan agenda wisata Boyolali.

Menurut Wahyuni (2018) pada tahap ini, masyarakat diberikan daya, otoritas, atau peluang untuk berkembang menuju kemandirian. Dari segi fisik, Dewi Sambi banyak mendapat bantuan dana pembangunan sarana pendukung wisata dari pihak pemerintah. Bantuan pembangunan tersebut didapatkan dari hasil kejuaraan lomba Dewi Sambi baik tingkat kabupaten, provinsi, maupun nasional. Selain dari hasil lomba, bantuan juga didapatkan dari anggaran pemerintah Kabupaten Boyolali untuk memperbaiki sarana dan prasarana Dewi Sambi.

Inovasi pengelolaan kuliner khas Kecamatan Selo merupakan salah satu pendayaan yang diterapkan Dewi Sambi. Kecamatan Selo merupakan salah satu kecamatan penghasil susu sapi murni di Kabupaten Boyolali. Daya simpan susu murni yang singkat menjadi faktor adanya inovasi kuliner susu. Dewi Sambi memberdayakan kelompok masyarakat setempat untuk membuat olahan susu. Hasil olahan tersebut yaitu dodol susu, permen susu, dan stik susu. Kelompok masyarakat tersebut merupakan bagian dari anggota Dewi Sambi, yang masuk ke kelompok UMKM.

\section{Kondisi perkembangan Dewi Sambi berdasarkan teori analisis TALC}

Teori analisis TALC (Tourism Area Life Cycle) dikemukakan oleh Butler(1980). Guna mengetahui perkembangan desa wisata Samiran Boyolali sampai tahap mana, dapat menggunakan teori ini. TALC merupakan teori siklus hidup pariwisata, sampai tahap mana keberlanjutan pariwisata. Teori tersebut terdiri dari 7 tahap, yaitu exploration, involvement, development, consolidation, stagnation, decline, dan rejuvenation. Setiap tahap memiliki ciri sendiri-sendiri.

a. Tahap exploration atau penjajakan memiliki ciri suatu wisata masih baru, fasilitas belum memadai, serta wisatawan mulai berdatangan dalam jumlah sedikit. Dewi Sambi pada tahap ini belum terkenal luas, fasilitas belum lengkap, informasi hanya disampaikan ke relasi, dan hanya memiliki paket wisata yang sederhana. Pada awal perkembangan Dewi sambi hanya menjual paket outbond di lapangan saja.

b. Tahap involvemet atau pelibatan memiliki ciri pengelola wisata menandai kapan saja yang menjadi musim wisata, dan wisatawan mulai bertambah. Suryaningsih dan Ida (2016) menambahkan pada tahap ini ditandai mulai adanya promosi dan inisiatif masyarakat lokal untuk membangun daerahnya. Dewi Sambi menggencarkan promosi desa wisata baik melalui selebaran maupun table top. Tahapan ini, Dewi Sambi mulai menetapkan fasilitas homestay-homestay yang bergabung untuk dijadikan paket menginap. Pemilik homestay mulai diberdayakan pada tahap ini.

c. Tahap development atau pengembangan memiliki ciri kebijakan publik dan investasi dibutuhkan jika daerah wisata mendukung pengembangan serta adanya penambahan atraksi buatan. Dewi Sambi memberdayakan beberapa tempat wisata buatan maupun alami yang berada di Desa Samiran. Namun, tempat wisata yang diajak kerjasama dengan Dewi Sambi adalah tempat wisata milik kelompok bukan perseorangan. Hal ini dimaksudkan agar pemberdayaan merata ke kelompok. Transportasi yang dimanfaatkan untuk mengantar tamu wisatawan mengelilingi wisata di Desa Samiran menggunakan mobil pick up yang dijuluki "pajero" (panas jobo jero). Mobil ini juga memiliki kelompok dan dijadikan mitra Dewi Sambi. Dewi Sambi juga menampilkan atraksi budaya tarian lokal kepada wisatawan yang memberdayakan kelompok kesenian setempat. Adanya fasilitas paket wisata "pasar tiban" memberdayakan kelompok ibu-ibu untuk menjual makanan tradisional dengan sedikit berbahan plastik. Alat transaksinya menggunakan duit bathok yang dilubangi ditengah berupa koin, untuk memanfaatkan limbah pembuatan jadah. Setiap koin senilai Rp 2000. Fasilitas paket petik sayur juga memberdayakan kelompok petani sayur, untuk dapat menyisihkan lahannya untuk di panen tamu wisatawan.

d. Tahap consolidation atau penggabungan memiliki ciri jumlah wisatawan terus meningkat, penyelenggaran sesuai peraturan, peran kementrian dan pemerintah untuk 
memperbaiki pelayanan kepada tamu wisata. Dewi Sambi semakin dikenal oleh wisatawan karena adanya berbagai ulasan positif di media elektronik. Jumlah kunjungan wisatawan dalam sebulan semakin meningkat menjadi 2-4 kali. Dalam pengembangan Dewi Sambi, pengelola menerapkan peraturan tegas yang berkaitan dengan desa wisata seperti masyarakat yang ingin bergabung ke desa wisata harus masuk ke kelompok, tidak merangkap ke kelompok lain (1 orang 1 kelompok), tidak menerima tamu homestay short-time atau pasangan tidak resmi, apabila ada pelanggaran akan diberikan sanksi tegas berupa SP (surat pelanggaran) dan jika tidak diindahkan, akan dikeluarkan dari manajemen desa wisata serta pencabutan hak yang dimiliki. Peran kementrian dan pemerintah dalam memperbaiki pelayanan tampak pada perhatian untuk memberikan bantuan rehabilitasi homestay, pemberian bantuan pinjaman dana untuk homestay, serta adanya pelatihan dan studi banding ke desa wisata yang lebih maju. Perkembangan Dewi Sambi sampai pada tahap ini.

e. Tahap stagnation atau stagnan memiliki ciri jumlah wisatawan mencapai puncak, fasilitas desa wisata menarik perhatian, membutuhkan promosi. Pada tahapan ini kunjungan wisatawan nusantara Dewi Sambi tertinggi pada tahun 2018, sejumlah 3206 orang. Namun jumlah tersebut dirasa belum mencapai puncak, karena promosi yang dilakukan Dewi Sambi masih sedikit mengandalkan aplikasi tour and travel. Dewi Sambi mempromosikan paket wisata melalui media sosial, traveloka, dan mister aladin.

f. Tahap decline atau kemunduran memiliki ciri jumlah wisatawan turun, pasar mulai jatuh, promosi perlu digencarkan lebih keras. Dewi Sambi merupakan desa wisata yang masih menggali potensi-potensi yang dimiliki Desa Samiran untuk dapat dijadikan edukasi maupun rekreasi. g. Tahap rejuvenation atau pembaruan peremajaan memiliki ciri muncul inovasi baru dan area wisata ditata ulang sehingga memberi warna baru. Dewi Sambi belum sampai pada tahap ini, dan masih fokus pada pemerataan pemberdayaan di setiap dusun-dusun Desa Samiran untuk menggali potensi.

Berdasarkan paparan komponen pariwisata di atas, maka dapat diuraikan kondisi perkembangan Dewi Sambi menurut analisis TALC (Tourism Area Life Cycle), telah berada pada fase consolidation atau penggabungan yang dapat dilihat pada grafik berikut ini:

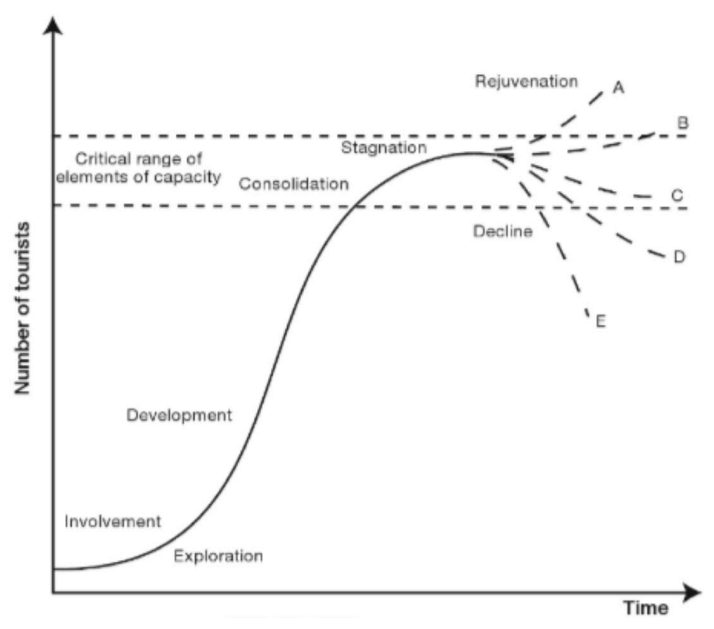

Sumber : Beeton (2006)

Kondisi perkembangan Dewi Sambi pada tahap consolidation atau penggabungan, dengan ciri yang tampak di lapang yaitu penyelenggaraan ketika ada tamu wisata maupun tidak sesuai dengan peraturan yang telah disepakati bersama. Selain itu juga ada beberapa kementrian maupun pemerintah yang membantu dalam rehabilitasi homestay maupun pelatihan pemilik homestay dan guide. Jumlah kunjungan tamu wisata Dewi Sambi mengalami fluktuatif namun cenderung meningkat. Dewi Sambi memiliki ketergantungan terhadap Gunung Merapi dan Merbabu, jumlah tersebut juga menyesuaikan dengan kondisi gunung. Jumlah kunjungan pada tahapan consolidation tersebut digambarkan pada Gambar 1. 




Tahun

Wisatawan Mancanegara Wisatawan Nusantara

Gambar 1. Jumlah Kunjungan Wisatawan ke Dewi Sambi

Berdasarkan data kunjungan wisatawan di atas terjadi kenaikan dan penurunan kunjungan. Kunjungan wisatawan tertinggi pada tahun 2018 untuk wisatawan nusantara, sedangkan tahun 2010 untuk wisatawan mancanegara. Tahun 2018 dan 2010 Gunung Merapi meletus dan pasca erupsi menarik kunjungan wisatawan. Sedangkan kunjungan wisatawan nusantara terendah pada tahun 2010, dan 2009 wisatawan mancanegara. Tahun 2009 Dewi Sambi dapat dikategorikan desa wisata yang masih baru dan sebagian besar wisatawan mancanegara belum mengetahui keberadaannya.

\section{KESIMPULAN}

Proses pemberdayaan Dewi Sambi melewati 3 tahapan yaitu tahap penyadaran, pengapasitasan, dan pemberian daya. Ketiga tahapan tersebut telah dilewati Dewi Sambi dan sebagian besar masyarakat Desa Samiran bergabung dalam Dewi Sambi. Selain itu, sejumlah $90 \%$ informan penelitian menyatakan bahwa perilaku negatif masyarakat Desa Samiran, yaitu membuang kotoran ternak di selokan depan rumah dan menjemur pakaian di jalan sudah tidak ada. Berdasarkan eksisting perkembangan pariwisata yang ada di Dewi Sambi, maka dapat disimpulkan perkembangan Dewi Sambi sejak ditetapkannya sebagai desa wisata yang diklasifikasikan menurut TALC (Tourism Area Life Cycle), bahwa perkembangan Dewi Sambi berada pada fase consolidation atau penggabungan. Tahapan tersebut dicirikan penyelenggaraan sesuai peraturan, jumlah kunjungan wisatawan fluktuatif namun cenderung meningkat sesuai pada grafik kunjungan wisatawan, dan adanya peran kementrian atau pemerintah untuk memperbaiki pelayanan kepada tamu wisata.

\section{DAFTAR PUSTAKA}

Andriyani, A. A. I., \& Edhi, M. M. (2017). Pemberdayaan Masyarakat melalui Pengembangan Desa Wisata dan Implikasinya terhadap Ketahanan Sosial Budaya Wilayah (Studi Kasus di Desa Wisata Penglipuran Bali). Jurnal Ketahanan Sosial 23(1) : 1-16.

Arifudin, Besri, N., \& Maswadi. (2013). Program of Community Empowerment Prevents Forest Fires in Indonesian Peat Land. International Journal of Procedia Environmental Sciences $17: 129-134$

Atmoko, T. P. H. (2014). Strategi Pengembangan Potensi Desa Wisata Brajan Kabupaten Sleman. Jurnal Media Wisata 12(2) : 146 -154

Bafadhal, A. S. (2018). Perencanaan Bisnis Pariwisata (Pendekatan Lean Planning). Malang : UB Press. 
Beeton, S. (2006). Community Development Through Tourism. Oxford Street : Landlinks Press.

Butler Richard, W. (2006). The Tourism Area Life Cycle Vol. 1 Application and Modification. Dufferin Street : Cromwell Press.

Darwis, V. (2012). Gerakan Kemandirian Pangan melalui Program Desa Mandiri Pangan : Analisis Kinerja dan Kendala. Jurnal Analisis Kebijakan Pertanian 10(2) : 159-179.

Febriani, N. N. S., I Gede, A.W., \& Wayan, T. (2014). Kajian Potensi Pasar Seni Sukawati sebagai Objek Wisata Budaya di Desa Sukawati Kecamatan Sukawati Kabupaten Gianyar (Tinjauan Geografi Pariwisata). Jurnal Pendidikan Geografi Undiksha 2(1) : 1-10.

Hermawan, H. (2016). Dampak Pengembangan Desa Wisata Nglanggeran terhadap Ekonomi Masyarakat Lokal. Jurnal Pariwisata 3(2) : 105-117.

Jamalina, I. A., \& Dyah, T. K. W. (2017). Strategi Pengembangan Ekowisata melalui Konsep Community Based Tourism (CBT) dan Manfaat Sosial dan Ekonomi Bagi Masyarakat di Desa Wisata Nglanggeran, Patuk, Gunung Kidul. Jurnal Ekonomi \& Studi Pembangunan 18(1) : 771-85.

Rani, D. P. M. (2014). Pengembangan Potensi Pariwisata Kabupaten Sumenep, Madura, Jawa Timur. Jurnal Politik Muda 3(3) : 412-421.

Steiner, A. A., \& Farmer, J. (2017). Engage, Participate, Empower: Modelling Power Transfer In Disadvantaged Rural Communities Environ. Plan. C: Polit. International Journal of Space 36 (1) : 118-138
Sugiyono. (2010). Metode Penelitian Kuantitatif, Kualitatif dan R\&D. Bandung: CV. Alfabeta.

Sururi, A. (2013). Pemberdayaan Masyarakat melalui Program Pembangunan Infrastruktur Pedesaan dalam Meningkatkan Kesejahteraan Masyarakat Kecamatan Wanasalam Kabupaten Lebak. Jurnal Administrasi Negara 3(2) : 1-25.

Sutawa, G. K. (2012). Issues on Bali Tourism Development and Community Empowerment to Support Sustainable Tourism Development. International Journal of Procedia Economics and Finance $4: 413-422$. Suryaningsih IAA, Ida BS. 2016. Posisi Desa Serangan Berdasarkan Analisis Tourism Area Life Cycle. Jurnal Destinasi Pariwisata 4(2) : 1-6.

Wahyuni, D. (2018). Strategi Pemberdayaan Masyarakat dalam Pengembangan Desa Wisata Nglanggeran, Kabupaten Gunung Kidul. Jurnal Masalah-masalah Sosial 9(1) : 83-100.

Wibowo. (2017). Rebranding Desa Wisata Kembang Arum untuk Meningkatkan Daya Saing Daerah di Bidang Pariwisata. Jurnal Dekave 10(1) : 61-72.

Wrihatnolo, R. R., \& Dwidjowijoto, R. N. (2007). Manajemen Pemberdayaan. Jakarta : Elek Media Komputindo.

Zakaria, E. R., Murni, S., \& Dedy, N. (2014). Analisis Posisi Keuangan. Jurnal Antara Bank Syariah dan Bank Konvensional di Indonesia 2(4). 